\title{
THE STUDY OF PHYSICAL FITNESS FOR THE STUDENTS OF MENTAL RETARDATION IN BENGKULU
}

\author{
${ }^{1}$ Feby Elra Perdima, ${ }^{2}$ Satria Agustian Lesmana \\ Correspondence: Dehasen University of Bengkulu, Bengkulu, Indonesia \\ E-mail: Perdima.elra@gmail.com
}

\begin{abstract}
Abstrak
Penelitian ini bertujuan mengetahui tingkat kesegaraan jasmani siswa Tunagrahuta di Sekolah Luar Biasa Kota Bengkulu. Menggunakan tes kesegaraan jasmani TKJI. Metode ini merupakan metode deskriptif kuantitatif pengembangan dari survei dengan tes pengukuran. Untuk mengembangkan norma tes kesegaran jasmani untuk siswa normal dan dijadikan norma tes sebagai acuan untuk siswa memiliki kebutuhan khusus terutama untuk siswa tunagrahita untuk melihat tingkat kesegaran jasmani. Sampel dari penelitian ini berjumlah 25 Orang teknik pengumpulan sampling menggunakan teknik purposive sampling. Hasil penelitian menunjukan tingkat kesegaraan jasmani tunagrahita di SLB Kota Bengkulu. 1 orang atau (4\%) berada pada katagori Baik Sekali. 3 orang atau (12\%) berada pada katagori Baik. 6 orang atau (24\%) berada pada katagori Sedang. 6 orang atau (24\%) berada pada katagori Kurang. 9 orang atau (36\%) berada pada katagori Kurang Sekali. Maka untuk meningkatkan kesegaran jasmani, perlu meningkatkan prinsip latihan yaitu proses perubahan ke arah yang lebih baik, diantaranya meningkatkan kualitas fisik, kemampuan fungsional tubuh dan aktifitas psikis seorang. Semakin tinggi aktifitas fisik yang dilakukan setiap hari akan semakin baik. Semakin baik juga dalam proses pertumbuhan dan perkembangan anak, tidak hanya merupakan tugas dari orang tua saja tetapi tugas dari sekolah juga. Guru pendidikan jasmani mempunyai peran yang sangat penting untuk membantu tercapainya kesegaran jasmani siswa. Dengan cara memberikan pembelajaran kesegaraan jasmani dan juga memberikan latihanlatihan kesegraan jasmani bagi siswa
\end{abstract}

\section{Kata Kunci: Kesegaraan Jasmani, Siswa Tunagrahita}

\begin{abstract}
This study aimed to determine the level of physical fitness of mental retarded students in Special School of Bengkulu by using the TKJI physical fitness test. This method was a quantitative descriptive method of development from surveys with measurement tests. To develop the physical fitness of test norms for normal students and to be used as test norms as a reference for students having special needs, especially for mentally retarded students in order to see the level of physical fitness. Samples from this study amounted to 25 people through a purposive sampling technique. The results showed the level of mental retardation in Special School of Bengkulu, namely 1 person or $(4 \%)$ was in the category of Very Good. 3 people or (12\%) were in the Good category. 6 people or $(24 \%)$ were in the Medium category. 6 people or $(24 \%)$ were in the category of Less. 9 people
\end{abstract}

PJKR_ 
or $(36 \%)$ were in the category of Very Less. Therefore, to improve the physical fitness, it was necessary to improve the principle of practice, namely the process of change in a better direction, including improving physical quality, body functional abilities and psychological activity of a person. The higher the physical activity was conducted every day, the better the level of physical fitness was. The better was in the process of growth and development of children, not only the task of the parents but the task of the school as well. Physical education teachers had a very important role in helping students to achieve physical fitness. The teachers could give by providing physical fitness lesson and also exercises for physical integrity for students.

\section{Keywords: Physical Fitness, Students of Mental Retardation}

\section{Introduction}

Sports activities are given from primary school level up to college. Therefore, school sports activities are included in the school curriculum as a means of supporting the growth and improvement of students' physical fitness. Sports activities in schools have a purpose in addition to increasing growth and physical fitness, also to improve achievement. Sports coaching and development in the last decade is very intensively carried out through schools, especially in primary schools. One of the subjects that participated fairly in creating quality Indonesian that is physically and spiritually healthy is the subject of physical health education.

Physical education is an integral part of the education system with physical activities as an educational medium. However, it does not mean physical education is education that only aims to develop the physical abilities of children, but through physical activity in general can also be developed cognitive potential, affective and psychomotor students. The level of physical fitness of a person can be increased from early age to adulthood through physical activity programs provided to the entire community as well as for the mentally disabled students in special schools in the city of Bengkulu.

Therefore, all special schools in the city of Bengkulu always provide material on physical activities to maintain the physical fitness of the mentally retarded students or to be improved. But, the problems encountered during observation and interviews with school teachers are usually as follows:

1. It has not yet known the level of physical fitness of mental retarded students

2. It has not yet known the norms of physical fitness tests for mental retarded students, but there are only TKJI test norms for Normal students

3. Mental retarded students are considered to have a lack of physical fitness

4. The teacher confusion of exceptional school students in determining the form of physical fitness tests to see students with disabilities.

PJKR_

http://jurnal.unimed.ac.id/2012/index.php/jpehr 
The observation results the researcher wants to solve these problems by making a reservation norms TKJI tests for normal students to be the test norms in accordance with students of Special Schools so that with the test norms and forms of physical fitness tests can help foreign school teachers can in determining the level of physical fitness of students and also with this study the results of physical fitness tests are in accordance with students with intellectual disabilities.

The initial planning of this study was to look at the level of physical fitness of special school students especially for students with physical disabilities through the Physical Fitness test with valid norms so that it became a benchmark for the physical fitness of these students. In this study, the scheme taken was the Beginner Lecturer Research (PDP) entitled The Study of Physical Freshness Test for Developmental Students in Bengkulu City. It is hoped that this research can be useful for teachers who teach in special schools to see the level of physical fitness of their students.

Sabaruddin Yunis (2016) physical education is a process which is conducted at every level starting from primary school to secondary school that uses physical activities or members to achieve physical health and fitness, movement skills that result in the development of attitude and intellectual abilities in daily life. This can be achieved with regular practice. Components of physical fitness related to health are aerobic ability, muscle strength, muscular endurance, flexibility and body composition associated with improved health.

Physical fitness is a reflection of the ability of functions and systems in the body that can realize an increase in the quality of life in every physical activity, physical fitness is a physical ability that can be trained through an aerobics ability training program, among others, can be known through the cardio respiratory system to provide oxygen needs until into the mitochondria, while the anaerobic ability is measured by the ability of aerobic arousal and the strength of muscle contraction, Meiriani Armen (2017). Physical fitness must link various factors called general factors including the provision of open space, increase in human resources and community participation to develop a healthy life through sports activities. Physical fitness is not only oriented to physical problems, but has a direction and orientation to efforts to improve the quality of human resources who have overall psycho-physical endurance. Factors that can affect physical fitness are: (1) Age, (2) Gender, (3) Heredity, (4) Food consumed, (5) Cigarettes, and (6) Exercise, Djoko Pekik Irianto (2004).

From the opinions of some of the experts above it can be concluded that physical fitness is the ability and ability of a person to do work or perform daily tasks with enough strength and endurance, without causing significant fatigue, so that there is still significant energy remaining used to enjoy the free time that comes suddenly or suddenly, where people who lack fitness will not be able to do it.

Ministry of National Education Jakarta Physical Quality Development Center Jakarta (2010) Indonesian Physical Fitness Test is one form of instrument that measures the level of physical fitness. In a physical fitness workshop in 1984

PJKR

http://jurnal.unimed.ac.id/2012/index.php/jpehr 
TKJI was agreed and set to be an instrument that applies throughout the territory of Indonesia. The basic consideration is that this instrument is entirely structured with the condition of Indonesian children. The organization of TKJI must be guided by the following basic principles:

1. All test items must be carried out in one unit time without interruption.

2. The grace period that occurs in the next transfer of the testes is no more than 3 minutes.

3. The sequence of the test items must be in accordance with the provisions, not be randomized

The article 15 of 2003 about National Education System Law, education consists of several types, namely general, vocational, academic, professional, vocational, religious and special education. Special Education is education for students who have difficulty in participating in the learning process because of physical, emotional, mental, intellectual, social, and / or potential disabilities and special talents, the National Education System Law of 2003.

Bear physical and / or mental disorders and / or behavioral disorders. In general, people with physical / mental disorders receive educational services in Special Schools. Special Schools (SLB) are the schools for school-age children who have "special needs". Guidelines for Implementing the National Education System In 1993, SLB educational institutions are educational institutions aimed at helping students with physical and / or mental, behavioral and social disabilities to be able to develop attitudes, knowledge and skills as individuals and community members in establishing reciprocal relationships with social, cultural and natural environment and can develop skills in the world of work or attend further education

Mumpuniarti (2003) that the characteristics of mild retarded children can be reviewed physically, psychologically and socially, these characteristics include:

1. Physical characteristics appear as normal children have few weaknesses in sensomotor abilities

2. Psychic characteristics are difficult to think abstractly and logically, lack the analytical ability, weak associations, weak fantasies, less able to control feelings, easily influenced by personality, less harmonious because they are unable to judge good and bad.

Social characteristics, they are able to get along, adapt to the environment that is not limited to families, but there are those who are able to be independent in the community, able to do simple work and perform fully as adults, abilities in education including being able to educate.

\section{Method}

This research was a quantitative descriptive research development from a survey with measurement tests. This type of research aimed to develop norms of physical fitness tests for normal students and used as a test norm as a reference for students having special needs especially for mentally retarded students to see the

PJKR_ 
level

of

physical

fitness.

Data collection in this study was conducted in March-December 2019. The targets achieved in this study were students with special needs who were in Bengkulu, especially aged $13-15$ years.

The population in this study was male students aged 13-16 years in special needs schools in Bengkulu. The samples in this study were 25 sons. Sampling in this study used purposive sampling technique.

Data collection techniques that will be carried out in this study are:

a) Observation.

b) Needs analysis. This stage is conducted by the researcher observing directly following the learning activities

c) Research design at this stage the researcher conducts a measurement test.

d) At this stage the researcher conducts data analysis to see the level of physical fitness.

The instrument used for the physical fitness tests for mild retarded students is exceptional students (ages 13-15 years) using the TKJI test. The TKJI test series is as follows:

1. Run 50 meters son, this test aims to measure speed

2. Lift the body, this test is to measure the strength and endurance of the arm muscles and shoulder muscles

3. Lie down, this test is to measure the strength and endurance of the abdominal muscles

4. Upright jump, this test is to measure the explosive power of the legs Running 1000 meters, this test aimed to measure the endurance of the heart and lungs.

In this study, a child's physical fitness test was scored using a value table. Value table was listed as in table value 1 . To classify the level of physical fitness of children, then norms were used as in table 1 of the Ministry of Education and Culture (2010).

tha Table 1. Indonesian Physical Fitness Value for Ages 13-15 Years,

\begin{tabular}{|c|c|c|c|c|c|}
\hline Run 50 m & Uplift Body & Sit Up & Upright Jump & Run 1000 m & Score \\
\hline s.d - 6,7" & $16-\mathrm{Up}$ & $38-\mathrm{Up}$ & $66-U p$ & 3'04" & 5 \\
\hline $6,8^{\prime \prime}-7,6^{\prime \prime}$ & $11-15$ & $28-37$ & $53-65$ & 3'05" - 3'53" & 4 \\
\hline $7,7^{\prime \prime}-8,7^{\prime \prime}$ & $6-10$ & $19-27$ & $42-52$ & 3'54" - 4'46" & 3 \\
\hline $8,8^{\prime \prime}-10,3^{\prime \prime}$ & $2-5$ & 8 s- 18 & $31-41$ & $4^{\prime} 47^{\prime \prime}-6^{\prime} 04^{\prime \prime}$ & 2 \\
\hline $10,4^{\prime \prime}$ etc & $0-1$ & $0-7$ & $0-30$ & $6 \prime 05 "$ - etc & 1 \\
\hline
\end{tabular}

Table 2. TKJI Norms of Children with mild Developmental Disabilities Age 1315 Years, Aji Sugiarto (2014)

\begin{tabular}{ccl}
\hline No & Total & \multicolumn{1}{c}{ Classification } \\
\hline $\mathbf{1}$ & $17-$ up & Very good (BS) \\
\hline $\mathbf{2}$ & $14-16$ & Good (B) \\
\hline
\end{tabular}




\begin{tabular}{lcl}
\hline $\mathbf{3}$ & $11-13$ & Moderate $(\mathrm{S})$ \\
\hline $\mathbf{4}$ & $8-10$ & Poor $(\mathrm{K})$ \\
\hline $\mathbf{5}$ & $5-7$ & Very poor $(\mathrm{KS})$ \\
\hline
\end{tabular}

The next step was about the technique used. In this research, the technique used descriptive technique with percentage, namely data analysis technique which aimed to provide a description of the level of physical fitness with the actual use of data techniques from the state or object under study by determining the value or number in the form of a percentage which was then used as a discussion for the problem that was the object of research.

The formula is:

Percentage $=\frac{\Sigma \text { Kategori }}{\Sigma \text { Total }} \times 100 \%$

Ket:

$\sum$ Category: TKJI results obtained include very good categories (BS), good (B), moderate $(\mathrm{S})$, poor $(\mathrm{K})$, very poor $(\mathrm{KS})$

$\sum$ Total: The number of students who are the object of research

\section{Discussion}

Based on the results of the study, a physical fitness test for mild retarded children aged 13-15 years was obtained. In this study the results of the category of physical fitness level of mild retarded children aged 13-15 years in Bengkulu could be seen in the following table:

Table 3. TKJI Children with mild Developmental Disabilities 13-15 Years

\begin{tabular}{lcc}
\hline \multicolumn{1}{c}{ Classification } & Total of Students & Percentage \\
\hline Very good (BS) & 1 & $4 \%$ \\
\hline Good (B) & 3 & $12 \%$ \\
\hline Moderate (S) & 6 & $24 \%$ \\
\hline Poor (K) & 9 & $36 \%$ \\
\hline Very poor (KS) & 25 & $100 \%$ \\
\hline Total & & \\
\hline
\end{tabular}

From the above table, the histogram could be drawn as follows:

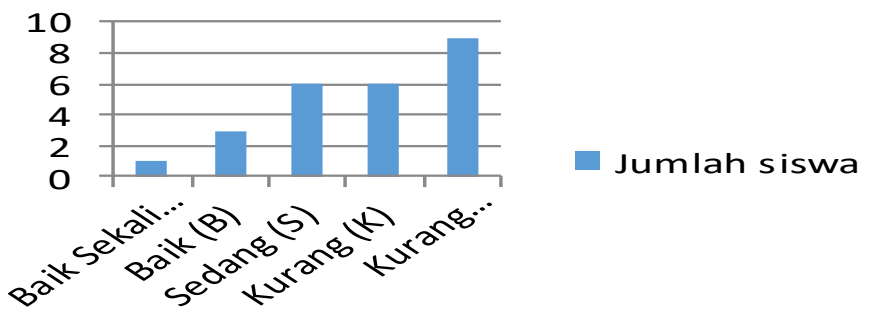

From the table and histogram above, we described the physical fitness level of mild retarded children aged 13-15 years in SLB Bengkulu City as follows: 
Based on the data in this study, the number of mild retarded children aged 13-15 years was 25 people, all of which consisted of sons. In accordance with the physical fitness table, which was included in the Very good category (SB) as many as 1 child (4\%), Good (B) as many as 3 children (12\%), Moderate (S) as many as 6 children (24\%), Poor (K) as many as 6 children (24\%), and Very poor (SK) as many as 9 children $(36 \%)$.

Physical fitness was the ability and endurance of one's physical or body in carrying out various activities of daily life, without experiencing significant exhaustion. Good physical fitness was needed by everyone to support their daily activities. No exception for mentally retarded students. Based on the results of the study above, it was known that the physical fitness level of mentally retarded students in SLB Bengkulu was mostly in the category of "Less" with an average value of 9.88 and 60 percent in the Less Categories. This was caused by the lack of physical activity and lack of movement.

Therefore, in order to improve physical fitness, it was necessary to improve the principle of practice which was the process of change for the better, including improving physical quality, functional ability of the body and psychological activity. The higher the physical activity carried out every day would be better. The better in the process of growth and development of children too, not only was the duty of parents, but the task of the school as well. Physical education teachers had a very important role to help the students achieve physical fitness. By providing physical fitness learning and also providing physical fitness training for students

\section{Conclusion}

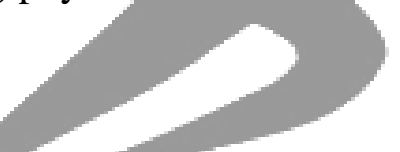

The results of the study showed that the physical fitness level of SLB Bengkulu students could be seen as a conclusion: 1 person or (4\%) was in the category of Very Good, 3 people or $(12 \%)$ were in the Good category, 6 people or $(24 \%)$ were in the Medium category, 6 people or $(24 \%)$ were in the Less category, 9 people or $(36 \%)$ were in the Very Poor category. The average overall SLB Bengkulu City students had a level of physical fitness in the category Less with an average value of 9.08 .

\section{References}

Djoko Pekik Irianto, 2000. Panduan Latihan Kebugaran (Yang efektif dan aman). Yogyakarta: Lukman Offset.

Kemendiknas, 2010. Tes Kebugaran Jasmani Indonesia. Jakarta: Pusat Pengembangan Kualitas Jasmani.

Meiriani Armen, 2017. Perbedaan Tingkat Kesegaran Jasmani Siswa SD Negeri 13 Muara Siberut Dengan Siswa SD Negeri 06 Rogdog Kecamatan Siberut Selatan, Journal Physical Education Health and Recreation. Volume: 2, Edisi: 1: 7-15.

Mumpuniarti, 2003. Ortodidaktik Tunagrahita. Yogyakarta: FIP UNY. 
Sabaruddin Yunis Bangun, 2016. Pengembangan Pengetahuan Anak Difabel Melalui Pendidikan Jasmani Olahraga dan Outbound. Journal Physical Education Health and Recreation. Volume: 1, Edisi: 1: 70-77.

Undang-Undang Nomor 20 Tahun 2003, Sistem Pendidikan Nasional. Jakarta: Presiden Republik Indonesia.

Undang-Undang No 3 Tahun 2005, Sistem Keolahragaan Nasional. Jakarta: Biro Humas dan Hukum, Kementerian Negara Pemuda dan Olahraga RI. 